\title{
SMEs in an Emerging Economy: Empirical Study on Corporate Governance Practices in SMEs Looking for Listing Option
}

\author{
Pravin Kumar Bhoyar ${ }^{1}$, Rajiv Divekar ${ }^{2}$, Asha Nagendra ${ }^{3}$ \\ \{pravink@sims.edu,director@sims.edu, asha.nagendra@sims.edu \} \\ Symbiosis International (Deemed University), Pune
}

\begin{abstract}
In 2003, Ministry of Corporate Affairs, Government of India, established National Foundation for Corporate Governance (NFCG) partnering with Confederation of Indian Industry (CII), Institute of Company Secretaries of India (ICSI) and Institute of Chartered Accountants of India (ICAI). In 2010, stakeholders in NFCG were expanded to include ICAI and National Stock Exchange. NFCG identified Symbiosis Institute of Management Studies (SIMS) as a partner institute to carry out projects pertaining to corporate governance. The objectives of this study were to understand the corporate governance practices of selected SMEs in Pune. Interviews were used to collect primary data. 16 companies which fulfilled corporate governance compliances were checked on selected parameters as: Private Equity Fund Association, Independent Directors, Board Meetings, Audit Committee, Transparency and Disclosures, Statutory Auditors, Investment Bank/Merchant banker Association, Growth sustainability exercise, Succession Planning, Industry, CEO category, Professional CA CS association, Employee participation in Governance. Investigators observed minimal material deviation in above parameters. The same rules governed both SMEs and large organizations for cost of borrowing, taxes, and IPR. There is a requirement to incentivize taxes for retention of earnings, subsidize employment and skills training, ease regulatory compliance for SMEs, and mandatory government procurement from listed SMEs.
\end{abstract}

Key Words: SMEs, Corporate Governance, NFCG, 'to-be-listed' companies

\section{Introduction}

\section{What is corporate governance?}

A number of definitions have been given to corporate governance. According to Mayer (1997)[1], "Corporate governance is concerned with ways of bringing the interests of (investors and managers) into line and ensuring that firms are run for the benefit of investors". Corporate governance is concerned with the relationship between the internal governance mechanisms of corporations and society's conception of the scope of corporate accountability (Deakin and Hughes, 1997)[2]. It has also been defined by Keasey et al. (1997) [3] to include "the structures, processes, cultures and systems that engender the successful operation of the organisations". Corporate governance is also seen as the whole set of measures taken within the social entity that is an enterprise to favour the economic agents to take part in the productive process, in order to generate some organisational surplus, and to set up a fair distribution between the partners, 
taking into consideration what they have brought to the organisation (Michaelas, et al). [4]. The Cadbury Committee (Cadbury, 1992,) [5] defines corporate governance as "the system by which companies are directed and controlled". Investopedia defines it as "Corporate governance is the system of rules, practices and processes by which a firm is directed and controlled. Corporate governance essentially involves balancing the interests of a company's many stakeholders, such as shareholders, management, customers, suppliers, financiers, government and the community".

From all these definitions, one can generalise stating that different systems of corporate governance will signify the legitimate lines of accountability by defining the correct nature of the relationship between the company and key corporate constituencies. Corporate governance systems may be therefore thought of as mechanisms for establishing the nature of ownership and control of organisations within an economy. In this context, corporate governance mechanisms are economic and legal institutions that can be altered."

\section{About National Foundation for Corporate Governance (NFCG)}

In October 2003, the Ministry of Corporate Affairs, Government of India set up the National Foundation for Corporate Governance (NFCG). This was done with a view of promoting some better corporate governance practices in India. The NFCG was set up in partnership with the Confederation of Indian Industry (CII), Institute of Company Secretaries of India (ICSI) and Institute of Chartered Accountants of India (ICAI). In 2010, ICAI and the National Stock Exchange were included as stakeholders in NFCG. Among its many objectives were fostering a culture for promoting good governance, voluntary compliance and to facilitate effective participation of different stakeholders. Further, it wished to create a framework of best practices, structure, processes and ethics and lastly, it was to make a significant difference to the Indian Corporate Sector by raising the standard of Indian corporate governance for achieving stability and growth.

Micro, Small and Medium Scale Enterprise (MSME): The definition of Micro, Small and Medium Scale Enterprise (MSME) varies from country to country. However, the common parameters used for defining MSMEs at international level includes; number of employees, total net assets, sales and investment level. The European Union version of definition for MSMEs according to total number of employers is as follows:

\begin{tabular}{ll}
\hline Number of Employees & Definition \\
\hline 0 & Self employed \\
$2-9$ & Micro business \\
$10-49$ & Small business \\
$50-249$ & Medium business \\
\hline
\end{tabular}

The Micro, Small and Medium Enterprises (MSME) Development Act of 2006, (India) attempts to define MSMEs for manufacturing and service sector according to plant \& machinery and equipment investments respectively. Accordingly MSMEs are defined as: 


\begin{tabular}{lll}
\hline Category & Manufacturing Sector & Service Sector \\
\hline Micro & Rs. 25 lakh & Rs. 10 lakh \\
Small & Rs. 5 crore & Rs. 2 crore \\
Medium & Rs. 10 crore & Rs. 5 crore \\
\hline
\end{tabular}

\section{Need for the Study}

Under management research, the issue of corporate governance is growing, especially among the large and listed firms. As there are limited studies in this area with respect to SMEs, it was considered crucial to examine the compliance of corporate governance in the SME sector. (Eisenberg et al., 1998 [6]; Bennett and Robson, 2004) [7].The compliance with codes of corporate governance has become the norm for listed firms all over the world. It is seen that in most countries, SMEs do not strictly comply with such codes but it has often been argued that such codes should also apply to these SMEs. This paper tries to examine the importance of good corporate governance in the SME sector, their compliance on various parameters, and the observations of corporate governance practices in the SMEs.

\section{Objectives}

The main objectives of the project were:

1. To understand the nature of the 'to - be - listed' SMEs

2. To observe the corporate governance practices of the selected SMEs.

\section{Review of Literature}

Zahra and Pearce (1989) [8] in their seminal contribution to board role research, reviewed extant board studies in an integrative perspective. In a research paper in 1992, they described the following three sets of interrelated roles which are played by boards in contemporary organisations: service, strategy and control. In 1996, Finkelstein and Hambrick (1996) [9] identified only two roles that the boards of directors perform in the organisation, without providing labels for these roles. Later, in the same year, Johnson, Daily and Ellstrand (1996) [10] enumerated three main roles for boards of directors; the control role, the service role, and the resource dependence role.

Family businesses are the most predominant form of organisation within the small and medium sized businesses. (Donckels and Fröhlich 1991, Corbetta and Montemerlo 1999). Their contributions to gross national products, job generation and wealth creation is extensive. (Beckhard and Dyer Jr. 1983, Shanker and Astrachan 1996, Kelly, Athanassiou and Crittenden 2000, Feltham, Feltham and Barnett 2005). All the same, in organisational and managerial research, this family business group is largely under represented (Schulze, Lubatkin, Dino and Buchholtz 2001, Dyer 2003, Steier, Chrisman and Chua 2004). Besides, majority of studies in corporate governance within family businesses are still focussing on large (publicly-traded) 
family firms, although the greater majority of these firms are much smaller (Handler 1989, Johannisson and Huse 2000). While focussing on large businesses, it contrasts with the claim that the role of the board of directors is more decisive for much smaller family firms (Castaldi and Wortman 1984, Nash 1988, Ward and Handy 1988, Ward 1992). Corbetta and Tomaselli (1996) claim that "a well-functioning board of directors can in fact be a critical resource for both family and business...". Therefore, the present study aims to contribute to the existing body of literature by empirically investigating board role performance and importance in a small and medium-sized family firm context. Research on board functioning within an SME-context is considered fragmented (Huse 2000) and is relatively in its infancy. Although a large number of authors have studied the roles of an SME's board, the present literature review very clearly illustrates that conceptual and methodological improvements could definitely enhance this field of study.

\section{Corporate Governance and SMEs}

Generally, one associates corporate governance with larger companies. One does not wish to believe that corporate governance would not apply to SMEs. In so many cases, SMEs sometimes comprise of only the owner who is the sole proprietor and manager (Hart, 1995). SMEs, basically, tend to have a less pronounced separation of ownership and management than larger firms. Some argue that because SMEs have few employees who are mostly relatives of the owner and thus no separation of ownership and control, there is no need for corporate governance in their operations. Also, the question of accountability by SMEs to the public is non-existent since they do not depend on public funds. Most, especially the sole proprietorship businesses do not necessarily need to comply with any disclosure.

\section{Benefits of Corporate Governance to SMEs}

There are those who advocate that the advantages of corporate governance should attract SMEs especially growing entrepreneurial firms to adopt it. This section looks at such benefits and discusses them, as well as highlighting them in the Ghanaian SME context. By definition, growing entrepreneurial firms are firms that have the growth and orientation to expand beyond their state of survival. The benefits of corporate governance to listed firms could apply to SMEs as well. In this case, the benefits that accrue from corporate governance practices further assist SMEs to grow rapidly.

Contribution and growth of MSMEs in India: MSMEs contribute significantly towards India's economy, also on the employment. Where value is concerned, this sector accounts for approx. $45 \%$ of the output in manufacturing and approximately $40 \%$ to the total exports of India. Throughout the country, MSMEs employ people who are almost 42 million. This is done in 13 million units. The products are more than 6000 in number, varying from traditional to high-tech items, manufactured by the Indian MSMEs. The statistics show that MSMEs have increased in India steadily from 67.87 lakhs in 1990-91 to 133.68 lakhs in 2007-08. Besides, number of people employed in MSEs has gone up from 158.34 lakhs in 1990-91 to 322.28 lakhs in 200708. However, the contribution of the MSE sector to the production in industry has declined negligibly from $39.74 \%$ in $1999-2000$ to $38.57 \%$ in $2006-07$. Regarding the gross domestic product (GDP), MSE contribution has increased from 5.86\% in 1999-2000 to $5.94 \%$ in 200607. Small scale industry exports has also increased from Rs.9,664 crore in 1990-91 to Rs. $1,50,242$ crore in 2005-06. There are predominantly eight groups of products in which MSMEs 
export. They are: Readymade garments, Engineering goods, Electronic and computer software, Chemicals and allied products, Basic chemicals, pharmaceuticals and cosmetics, processed foods, Finished leather and leather products and Plastic products. These account for more than $90 \%$ of all exports.

\section{Clause 49 of the Listing Agreement}

All companies wanting approval for listing are covered under the provisions of this Clause.

On January 13, 2006, the revised Clause 49, came into effect. In this, SEBI issued some further clarifications on Clause 49 which included:

1. Maximum time gap between board meetings of listed companies needs to be increased from three to four months.

2. Prior approval of shareholders is not needed for sitting fees to be paid to non-executive directors.

3. Certifications of internal controls and internal control systems by CEOs and CFOs would cover financial reporting only.

In July 2007, further amendments were made which dealt with quarterly reporting. SEBI made it optional for companies to present either an audited or unaudited result quarterly as well as year to date financial results to Stock Exchanges within one month from the end of each quarter.

Source: NFCG report titled, "Corporate Governance Practices and Financial Performance of Selected Family Managed Medium Sized Listed Companies in India”.

\section{Mandatory Provisions}

There are certain mandatory provisions under this Bill. They are:
a) Board of Directors
b) Audit Committee
c) Subsidiary companies
d) Disclosures
e) $\mathrm{CEO} / \mathrm{CFO}$ Certification
f) Separate Section in Company's Annual Report on Corporate Governance.
g) Compliance certificate from Auditors or practicing Company Secretaries

\section{Management and Administration}

Annual Returns should include additional Information: Certain additional information like particulars of the company's holdings and subsidiary and associate companies need to be mentioned in the Annual Returns. Certification of annual return by a practicing company secretary is mandatory for companies with prescribed paid up capital and turnover.

Corporate Social Responsibility: When a company has a net worth of Rs. 500 crore or more or turnover of Rs. 1,000 crore or more or a net profit of Rs. 5.0 crore will have to constitute a 
Corporate Social Responsibility Committee of the Board. This committee should consist of three or more directors (at least one of them should be an independent director). At least two percent of the average net profit of the company made during the three immediately preceding financial years should be spent in pursuance of the CSR policy. If this is not done, it should be reported in the Directors' report with reasons given. This enables promoters and directors of the company to fulfil the function of giving back to the Society. Till now it was considered as just a compulsion with some funds spent on it. Under this Law, now companies will have a commitment to make sure that the mandatory share of profits are directed into CSR activities every year. This will help in inclusive growth and reforms of social sector.

Appointment of Independent Directors (IDs): The current policies relating to the appointment of Independent Directors and their determination has been highly criticized. It is seen that the promoters always exert too much of influence in determining and appointing Independent Directors. To solve this problem, now, it is made mandatory for all listed and other class of companies to constitute a Nomination and Remuneration committee which consists of three or more Non- Executive Directors of whom not less than $50 \%$ should be Independent Directors. Candidates have to be considered for appointments as IDs and then recommended to the Board. The Bill suggests the formation of a Databank of IDs from which, whenever needed, suitable persons may be selected. It is clearly written that there should be at least one woman director on the Board.

Role and Functions: The role, functions and duties of the Independent Directors are laid down in Section IV. Besides, the rules relating to their appointment, resignation and evaluation are also outlined. These rules clearly tell us how important is the role of the Independent Directors and this leads to proper monitoring of the listed companies which in turn leads to good corporate governance practices.

\section{Methodology}

The primary objective of the study is to investigate the corporate governance practices in 'tobe- listed' SMEs in Pune region who are in the process of preparation of listing of their shares in Stock Exchanges. The investigators adopted exploratory research method for the investigation with emphasis on primary data collected using questionnaire and interviews. The scope is also limited to compliance of the present requirements of the listing agreement with Stock Exchanges and in particular clause 49 of the same. Clauses cited hereunder against each of the issues covered are only the major pointers of the clauses of the Listing agreement which to be listed companies are expected to meet on listing. The newly introduced Corporate Governance practices under the Companies Act 2013 is out of scope of this study as the visits to the units were made before the new law was enacted.

Sample Size and Distribution: A sample size of 16 SMEs which satisfied the requirements for the study were selected. Among these, 12 companies were pertaining to manufacturing sector while 4 companies were representing real estate sector. IT and Services industries were also included as a category but the investigators did not find companies fitting the research criteria for the aforementioned sectors. The investigators have not mentioned the names of the companies confirming to the confidentiality request made by the target companies. 
Parameters for Evaluation: The researchers identified various parameters for analysis and these were used to create a check list:

- Private Equity Fund Association

- Independent Directors

- Board Meetings

- Audit Committee

- Transparency and Disclosures

- Internal Audit

- Statutory Auditors

- Investment Bank / Merchant banker association

- Growth sustainability exercise

- Succession Planning

- Industry

- CEO category

- Professional CA CS association

- Employee participation in Governance

Private Equity Fund Association: Private Equity firms not only act as financial investors but also occasionally guide companies on operational matters like human resource management, diversification, business focus etc. In addition the private equity players will be vigilant on the business moves and business evolution of the company. The investigators categorized the PE fund into two categories for this study. 1. Short term PE fund, the duration of which was less than 3 years and 2. Long term PE fund, the duration of which was greater than 3 years.

Independent Directors [Clause 49(I) (B)]: The Listing Agreement, clause 49(I)(A)(i) strives for optimum combination of executive and non-executive directors, with at least half of the board comprising of nonexecutive directors. However the minimum number of independent director varies in accordance with chairman on board. In the event of the chairman holding an executive position in the company, at least one half of the board should consist of independent directors, and where the chairman is in a non-executive capacity, at least one third of the board should consist of independent directors. An independent director is defined as a non-executive director who: apart from receiving director's remuneration, does not have any material pecuniary relationships or transactions with the company, its promoters, its directors, its senior management or its holding company, its subsidiaries (clause 49(I)(A)(iii)(a)). The governance reforms under the Kumar Mangalam Birla Committee highlighted the relationship between investor perception and corporate governance. A temporal frame of 2 days from 7 May 1999 witnessed a share price increase of $4 \%$ of the firms who intended to inculcate corporate governance reforms (Varottil, 2010). This widely established the investor confidence on corporate governance which they perceived to limit the independence of the directors. 
For this study, the investigators classified the number of independent directors into two categories:

a) Number of independent directors being two; and

b) Number of independent directors being more than two.

Board Meetings [Annexure 1A of clause 49]: Directors are, however, required to ensure some minimum commitment towards boards on which they sit. Companies are required to have at least four board meetings a year (Id., clause 49(I)(C)(i)). Apart from that, there may be meetings of various committees of the board that directors are required to attend if they are members of such committees. Towards that end, there are maximum limits as to the number of boards and committees on which independent directors can sit. An independent director cannot be a member of more than 10 committees or act as chairman of more than 5 committees across all companies.

The investigators classified the number of board meeting into two categories for this study:

a) Number of board meetings conducted as 4 per year, and

b) Number of board meetings conducted as more than 4 per year.

\section{Results and Observations}

\section{CEO Category \& Presence of CA/CS}

It was found that out of 16 companies, 12 companies had promoters as their CEO. On the other hand, only 9 companies were found to have a professional CA/CS association

Expected: The CEO shall be one totally understanding the business and being SME normally is the promoter who started the business but expect certain important functions of the business be delegated to independent professionals who are experts in the subject. Eg., Marketing (for scaling the business), Production (for meeting marketing needs), Finance (for exploring all sources of finance, disclosures, internal controls etc.), Legal and Company Secretarial (for regulatory compliance requirements).

Association of CA and CS is to meet compliance and controls requirements and assist the Independent Directors and Audit committee in their due discharge of their responsibilities.

Actual: Though it was noted that except in a few cases the CEO job is retained by the promoters. However delegation of certain core functions like Finance, Marketing and Legal have been delegated to professionals by appointing them. In certain cases though CA or CS have not been taken in the company, professional CA or CS have been retained for rendering the services on the ground that full time appointment is not only expensive but full time work or such professionals have not yet arisen and may happen only after listing and reasonable scaling of the activity of the company.

Material Deviations: No material deviations have been noticed as the SME's are yet to be listed but have taken steps to meet requirements well in advance. 
PE Fund: The investigators found that 4 companies out of 16 had long term PE funds (greater than 3 years) on the other hand 12 companies had short term PE fund (less than 3 years)

Expectations: PE funding is generally seen as a first step to listing of the shares. Their evaluations and association helps in inculcating the good and transparent governance practices required to meet the listing requirements on Corporate Governance.

Actual: PE funding had created an atmosphere of professionalism in the organization and at least in the approach of the promoter group. Their exit routes generally being through the listing process, steps to get the shares listed is also an agenda of the SME's as stipulated by the PE Funds.

Material Deviations: No material deviations were noticed

Independent Directors [Clause 49(I) (B)]: The investigators found that 4 companies out of 16 had more than 2 independent directors. 12 out of 16 companies had 2 independent directors.

Expectations: To evaluate whether the SME's have come out of the old system of closed governance to actual participation in meetings along with the Independent Directors who are unrelated to the promoters.

Actual: Though on record Independent Directors have been taken, but are mostly technical or marketing personnel who are experts who could contribute in the growth of the business.

Material Deviations: Complete details are unavailable to evaluate the independence of the Independence Director. However such appointments itself is a step towards better transparency and governance.

Board Meetings [Annexure 1A of clause 49]: The investigators found that all the 16 companies conducted 4 board meetings a year.

Expectations: To evaluate whether actual meeting of the members of the board happens and whether papers and transparency exist, deliberations and discussions happen on crucial issues and decisions are taken considering all aspects. Also to ensure whether board papers are prepared in advance and proper recording of the proceedings are done. Also to evaluate how many such meetings happen every year

Actual: From the information gathered and explanations given it was noted that due to the presence of PE Fund representatives and Independent Directors intake crucial decisions, actual meetings are held, sometimes even more than the statutory minimum of 4 meetings in a year happen, papers are distributed 7 days in advance to the members attending the board meet and proper recordings are made by way of minutes, as per law.

Material Deviations: No material deviations have been noticed but scope to improve could not be ascertained.

Audit Committee [Clause 49(II)]: The investigators found that all 16 companies had established an audit committee.

Expectations: To evaluate whether Independent Director heads the Audit committee, all important financial statements like quarterly results etc. are first reviewed and then sent to the Board for their approval. Also whether the terms of reference for appointment of the Internal Auditors are reviewed and discussed at Audit Committee meetings. 
Actual: Though the committee is formed complete functions of the Audit Committee of a listed company is not being followed, Improvements are being made to reduce the burden of the Board in taking the decisions. Interactions with Internal Auditor, CFO, CS, Professionals etc., are seen happening by way of Governance improvements.

Material Deviations: Steps in the right direction have been taken though the scope is known to increase after listing of the shares.

Transparency and Disclosures [Clause 36 \& 46]: The investigators found sufficient mechanisms for transparency and disclosures in 4 out of 16 companies. The remaining 12 companies need to do more for improving transparency and disclosure.

Expectations: Whether actual documentations and less of verbal discussions happen to reduce differences and helps participation in the organization. Proper communication channels are in place to communicate to the concerned. This is expected to improve Governance standards.

Actual: In most cases due to the implementation of the technology and computer setups and emails, transparency and disclosures are improving. More disclosures are to meet compliances. Scope to improve communications always exists, which are being addressed.

Material Deviations: No material deviations have been observed

Internal Audit [Clause 49(IV), Annex IC to Cl.49, Clause 49(1)(d) sub clauses 6, 7,8, \& 9]:

The investigators noticed an absence of internal audit system in 4 companies out of 16 .

Expectations: Purpose was to evaluate whether competent personnel is conducting the Internal Audit. Also whether their terms of reference cover important control areas and exposure of weaknesses and their reports and suggestions are considered by competent personnel for implementation.

Actual: Though the Internal audits are conducted and sometimes by audit firms who charge less as the cost factor is also considered. Whether the purposes are achieved are not in full is unascertainable.

Material Deviations: Compliance more than improving governance standards were observed.

Statutory Auditors [Clause 49(1) (d) sub clauses 2, 3, 4, 6, \& 10]

Expectations: To review whether in the expectation of going for listing whether the companies have even considered reputed Statutory Auditors including the big 4 firms.

Actual: In most cases no such changes were noticed. In some cases where PE fund investments have taken place, Auditors change has happened and in one case even from the big 4 is chosen.

Material Deviations: Cost and benefit analysis do not permit such changes immediately and hence can only expected to improve after scaling and listing of the company shares.

Investment Bank/ Merchant banker association [Clause 23, 24 (c), 24 (d) (ii)]: 4 companies out of 16 reported Investment bank association.

Expectations: This aspect was to evaluate whether there is scope for immediate listing of the company's shares and whether preparation to meet requirements of listing has started or not. 
Actual: In most cases except a few, no association of the Investment / Merchant Banker has taken place. But all of the units are aware of such association before the listing and hence are getting prepared for such association.

Material Deviations: Too early to evaluate.

Growth sustainability exercise [Clause 36]: 12 out of 16 companies were actively involved in growth sustainability exercises.

Expectations: This aspect was to evaluate whether the scope for scaling and sustainability for a long time exist in the organizations. Also it helped to evaluate the capability of scaling beyond the funding part.

Actual: All the companies are startups and / or of young age with lot of drive and competence of the promoters who understand the business. Scaling scope is seen mostly within the country but less on exports and international trade or services. Growth and sustainability scope exist.

Material Deviations: No deviations were observed

Industry: 12 companies were from manufacturing and 4 were from real estate industry

Expectations: This was to evaluate whether there was any specific difficulty or hindrance for any specific sector of the business. Manufacturing, Real Estate, IT Services etc., were in the survey list.

Actual: Sector wise specific problems were not observed. In all cases the general observation is inability to satisfy the mismatch between cost of compliance and the benefit from such compliances by listing the shares.

Succession Planning [Clause $36 \mathrm{r}$ w responsibilities of board in Annexure 1A to clause $49 \mathrm{r}$ w principle VI (D) (3) of OECD principles of Corporate Governance]: 4 out of 16 companies had given a thought for succession planning.

Expectations: This was to evaluate whether the organization has even thought of a succession plan of the CEO as it is material for sustainability and governance.

Actual: Majority of the organizations have never thought of such eventualities.

Material Deviations: There is scope for education and training of the promoters to understand the benefits from such planning process. 
Table 1: Corporate Governance compliance of 16 selected SMEs on selected parameters

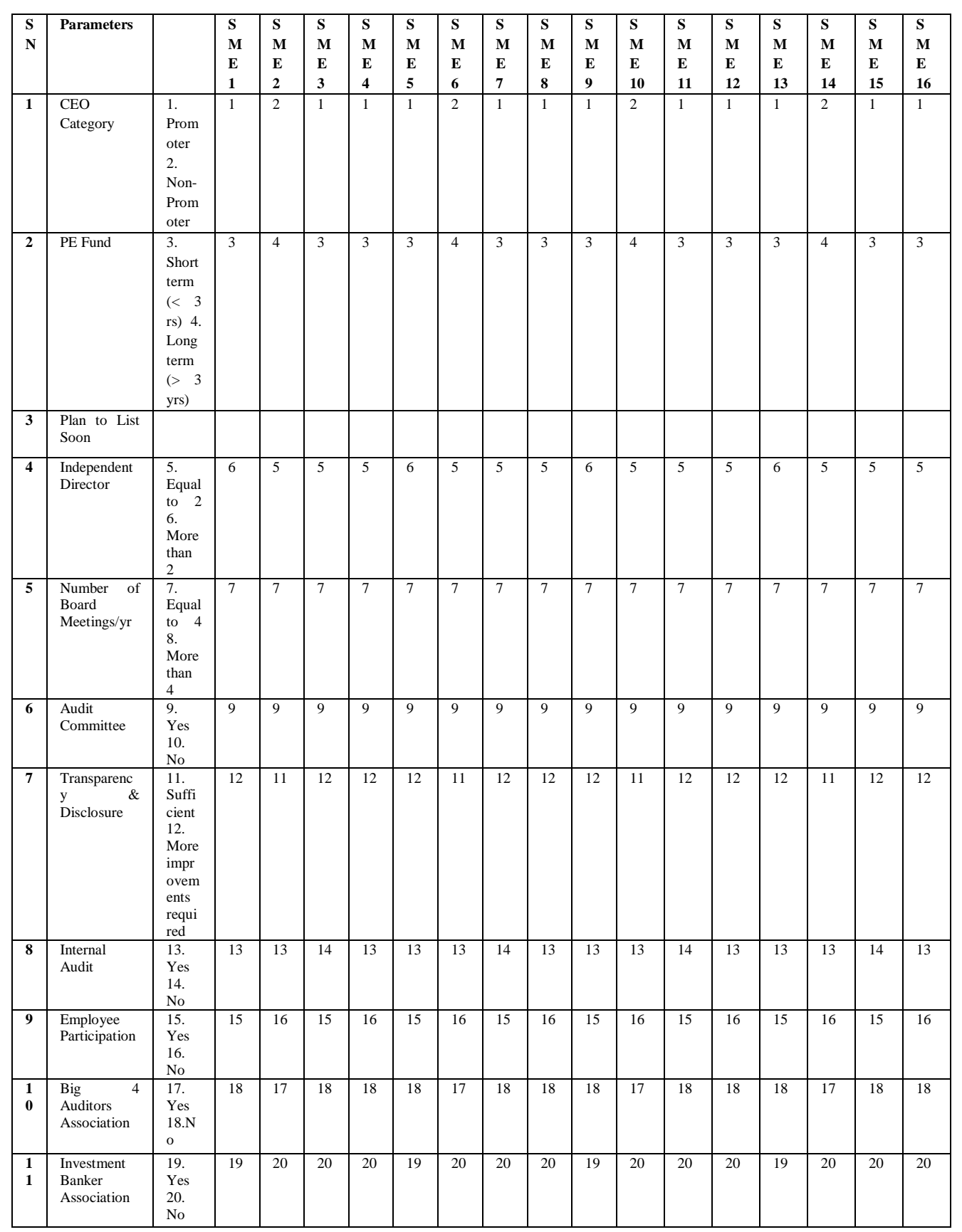




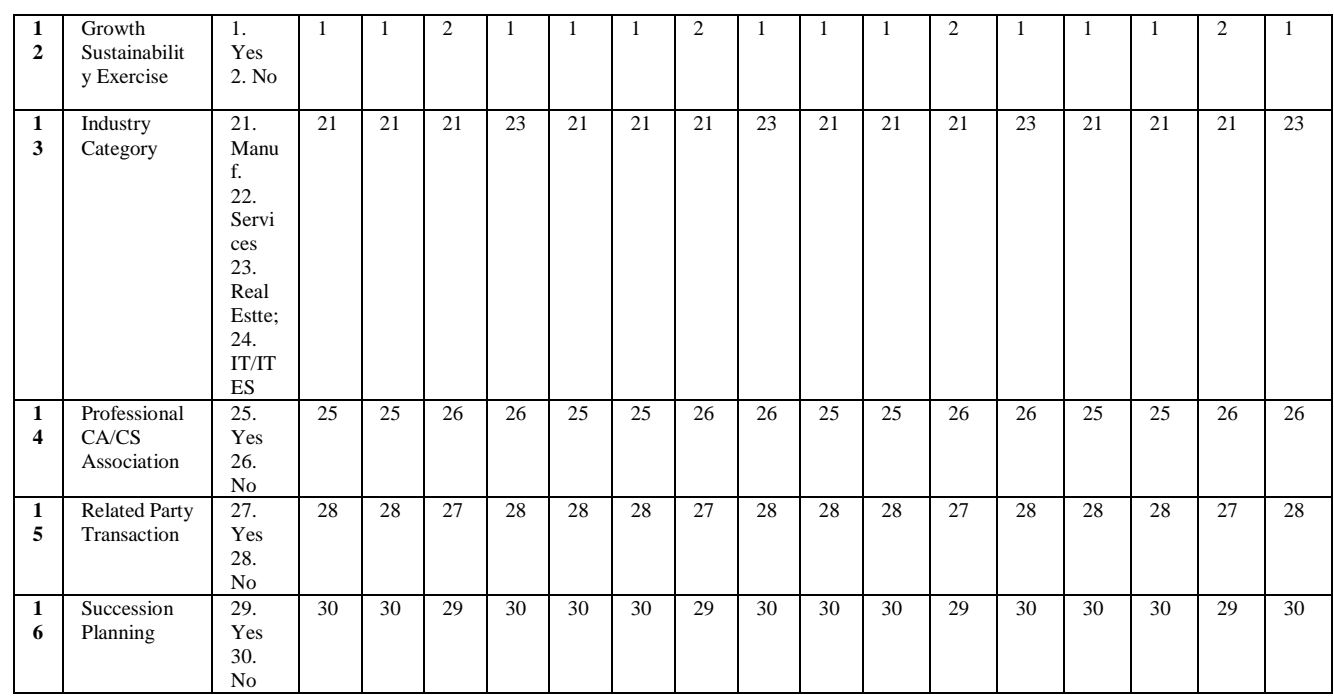

\section{Conclusions and Recommendations}

Results showed that all the companies interviewed were sincere in their efforts for compliance to meet listing standards. The investigators observed minimal material deviation in the key corporate governance parameters. The basic observations show same set of rules governing both SMEs and large organizations for cost of borrowing, taxes, and IPR. There is a requirement to incentivize taxes for retention of earnings, subsidize employment and skills training, ease regulatory compliance for SMEs, and mandatory government procurement from listed SMEs. Recommendations are skewed towards improving barriers to SME which would eventually lead them to adopt more effective corporate governance practices.

Recommendations are based on observations during the assessment of several SME's who are planning and / or in the process of getting their shares listed in SME exchange. The Table 1 below shows the comparison between the features of the 16 companies selected.

Cost of raising capital: The cost of raising capital for SME is high. This is a discouragement for any step towards listing by SME's. Hence they prefer borrowings as a tool to financing against capital raising. SEBI regulations including Merchant Bankers fees, issue procedures and cost of prospectus etc. are so high a major expenditure goes away from the raised capital. No special concessions for SME's to reduce cost exist.

Incentives to get IPR to be provided: SME's are in the same level of getting IPR's with large organizations and is becoming a discouragement for their attempt to get IPR's which only will enable them to scale their operations. Special incentive and removal of regulatory hurdles to encourage more IPR's for SME's is necessary for their value creation and encouragement to raise capital by listing. 


\section{Tax incentive for retention of earnings needed to be extended}

Tax burden for partnerships in retained earnings as compared to Corporate SME's are much less acting as a deterrent to convert to listed companies. Taken together, Corporate Tax and dividend distributions tax is high and a deterrent to development of SME's and their listing.

\section{Employment generation and skill training provided by SME has to be subsidized}

It is recognized that better skill development and training ground for youngsters are SME's and are always known for creating skilled employment. No special incentive for such contribution to national cause is recognized by way of incentive, which is necessary as an encouragement for SME's and their listing to capitalise on value created by such incentives.

\section{Regulatory compliance need to be eased for SME}

Even the recently introduced Companies Act, 2013 does not list any incentive from strict regulatory hurdles for SME's as compared to a large listed company form Corporate Governance compliance requirements making costs prohibitive for SME's to only adhere to the compliance .

Compulsory Govt. procurement from listed SME's need encouragement: Government procurement and/or large private sector procurement from SME's need encouragement by way of compulsory thresholds (percentage) to encourage large enterprises to outsource and build SME's. Separate thresholds for listed and unlisted SMEs will further encourage listings.

Thin capitalization rules and interest cap will encourage SME listings: SME's generally reinvest their initial earnings back to the business and discourage distribution of dividends which is a deterrent to listing as retail shareholders do not participate in such investments. Long term value creation is less on the agenda of the retail investors. Interest cap for unlisted SME's / Partnerships say Interest as percentage of EBIT will encourage SME listings by raising capital, which may European countries have successfully done through thin capitalization rules.

CG exemption for SME shares need improvement over large companies: Presently Income Tax on Capital Gains of listed companies large or SME is same and no incentives exist for an investor to participate in SME capital. Special incentive for SME capital gains tax both short term and long terms is required.

MAT rules for SME's need to be different: Minimum Alternate Tax applicable for corporates apply equally for SME's which has to be different if the government is serious of promoting SME listings. Say exemption for first 5 years from listing etc. will be encouraging.

All barriers for high cost of doing business to be brought down: Basic problem for SME's are their high cost of doing business and their lesser capacity to absorb compliance costs and deal with red tape. Any incentive which will result in reducing their cost of doing business will be an encouragement for many more SME's going for raising capital and rely less on borrowed capital. If compliance is a necessity and effective it has to be affordable or else the compliance will be in letter and not spirit and entire objective of such regulation get defeated. 


\section{References}

[1]. Mayer, F. (1997), "Corporate governance, competition, and performance", in Deakin, S. and Hughes, A. (Eds), Enterprise and Community: New Directions in Corporate Governance, Blackwell Publishers, Oxford.

[2]. Deakin, S. and Hughes, A. (1997), "Comparative corporate governance: an interdisciplinary agenda", in Deakin, S. and Hughes, A. (Eds), Enterprise and Community: New Directions in Corporate Governance, Blackwell Publishers, Oxford. [Google Scholar] [3]. Keasey, K., Thompson, S. and Wright, M. (1997), "Introduction: the corporate governance problem: competing diagnoses and solutions", in Keasey, K., Thompson, Maati, J. (1999), Le Gouvernement d'Entreprise, De Boeck Université, Paris and Bruxelles.

[4]. Michaelas, N., Chittenden, F. and Poutziouris, P. (1999), "Financial policy and capital structure choice in UK SMEs: empirical evidence from company panel data", Small Business Economics, Vol. 12, pp. 113-30.

[5]. Cadbury, A. (1992), Report of the Committee on the Financial Aspects of Corporate Governance, Gee Publishing, London. [Google Scholar]

[6]. Eisenberg, T., Sundgren, S. and Wells, M.T. (1998), "Larger board size and decreasing firm value in small firms", Journal of Financial Economics, Vol. 48 No. 1, pp. 35-54.

[7]. Bennett, R.J. and Robson, P.J.A. (2004), "The role of board of directors in small and medium-sized firms", Journal of Small Business and Enterprise Development, Vol. 11 No. 1, pp. 95-113. [Link], [Google Scholar] [Infotrieve]

[8]. Zahra, S. (1991), "Predictors and financial outcomes of corporate entrepreneurship: an explorative study", Journal of Business Venturing, Vol. 6 No. 4, pp. 259-85.

Abor J. and Adjasi, C. (2007). Corporate governance and the small and medium enterprises sector: theory and implications. Corporate Governance: International Journal of Business in Society, Vol. 7 No. 2, pp. 111-22. https://doi.org/10.1108/14720700710739769

Anheier, H.K. and Seibel, D. (1987), Small-scale Industries and Economic Development in Ghana: Business Behaviour Strategies in Informal Sector Economies, Cologne Development Studies series No. 3, Verlag Breitenbach Publishers, Cologne. [Google Scholar]

Baah-Nuakoh, A. and Teal, F. (1993), "Economic reforms and the manufacturing sector in Ghana", report for The Africa Regional Program of Enterprise Development, World Bank, Washington DC. [Google Scholar]

Berglof, E. and von Thadden, E.-L. (1999), "The changing corporate governance paradigm: implications for transition and developing countries", paper presented at the Annual World Bank Conference on Development Economics, Washington, DC. [Google Scholar] Claessens, S., Djankor, S., Fan, J.P.H. and Lang, L.H.P. (2002), "Disentangling the incentive and entrenchment effects of large shareholders", The Journal of Finance, Vol. 57 No. 6, pp. 2741-71. [Crossref], [ISI], [Google Scholar] [Infotrieve]

Carney, M. (2005). Corporate Governance and Competitive Advantage in Family-Controlled Firms. Entrepreneurship Theory \& Practice, 29(3), 249-265.

Corbetta, G. and Salvato, C.A. (2004). Boards of directors in Italian family businesses. Family Business Review, Vol. XVII No. 2, pp. 119-34.

Deakin, S. and Slinger, G. (1997), "Hostile takeovers, corporate law and the theory of the firm”, Journal of Law and Society, Vol. 24 No. 1, pp. 124-51. 
Department of Trade and Industry (2001), "Small and medium enterprise (SME) definitions", Corporate Governance Practices and Financial Performance of Selected Family Managed Medium Sized listed Companies in India - By SPJIMR, 2012

Freeman, E. (1984), Strategic Management: A Stakeholder Approach, Pitman, Boston, MA. Friedman, M. (1970), "The social responsibility of business is to increase profits", New York Times Magazine, 13 September, p. 33.

Fiegener, M. K. (2005). Determinants of Board Participation in the Strategic Decisions of Small Corporations. Entrepreneurship: Theory and Practice, 29(5), 627-650.

Ghatak, S. (2010). Micro, Small and Medium Enterprises (MSMEs) in India: An Appraisal. The Karve Committee Report. (1955)

Gibson, K. (2000), "The moral basis of stakeholder theory", Journal of Business Ethics, Vol. 26, pp. 245-57.

Gockel, A.G. and Akoena, S.K. (2002), "Financial intermediation for the poor: credit demand by micro, small and medium scale enterprises in Ghana. A further assignment for financial sector policy?", IFLIP research paper 02-6, International Labour Organisation, Geneva.

Guth, W. and Ginsberg, A. (1990), "Guest Editors' introduction: corporate entrepreneurship", Strategic Management Journal, Vol. 11, pp. 297-308.

Hart, O. (1995), "Corporate governance: some theory and implications", The Economic Journal, Vol. 105 No. 430, pp. 678-98.

Heath, J. and Norman, W. (2004), "Stakeholder theory, corporate governance and public management. What can history of state-run enterprises teach us in the post-Enron era?", Journal of Business Ethics, Vol. 53, pp. 247-65.

Hong Kong Institute of Directors (2014), Guidelines on Corporate Governance for SMEs in Hong Kong (3rd edn). <http://www.hkiod.com/sme-guidelines.html>, accessed 19 May 2015.

Hornsby, J.S., Kuratko, D.F. and Zahra, S.A. (2002), "Middle managers' perception of the internal environment for corporate entrepreneurship: assessing a measurement scale", Journal of Business Venturing, Vol. 17, pp. 253-73.

Investopedia.

The Challenge of Employment in India: An Informal Economy Perspective (NCEUS, 2009) IFC (2011), IFC Family Business Governance Handbook $<$ http://www.ifc.org/wps/wcm/connect/Topics_Ext_Content/ifc_external_corporate_site/cor porate+governance/publications/guidelines_reviews+and+case+studies/ifc+family+busines s+governance+handbook>.

Jenkinson, T. and Mayer, C. (1992), “The assessment: corporate governance and corporate control", Oxford Review of Economic Policy, Vol. 8 No. 3, pp. 1-10.

Jensen, M. (1993), "The modern industrial revolution, exit, and the failure of internal control systems", The Journal of Finance, Vol. 48 No. 3, pp. 831-80.

John, K. and Senbet, L. (1998), "Corporate governance and board effectiveness", Journal of Banking and Finance, Vol. 22 No. 4, pp. 371-403.

Jordan, J., Lowe, J. and Taylor, P. (1998), "Strategy and financial policy in UK small firms", Journal of Business Finance and Accounting, Vol. 25 No. 1, pp. 1-27. 
Kamar E., Karaca-Mandic P. and Talley E. "Sarbanes-Oxley's Effects on Small Firms: What is the Evidence?" Harvard Law School John M. Olin Center for Law, Economics and Business, Discussion Paper No. 588, July 2007.

Kuratko, D.F. (1993), "Intrapreneurship: developing innovation in the corporation: advances in global high technology management”, High Technology Venturing, Vol. 3, pp. 3-14.

López, G.J. and Aybar, A.C. (2000), "An empirical approach to the financial behaviour of small and medium sized companies”, Small Business Economics, Vol. 14, pp. 55-63.

McGahan, A.M. and Porter, M.E. (1997), "How much does industry matter really?", Strategic Management Journal, Vol. 18, Summer, pp. 15-30.

Merrifield, D.B. (1993), "Intrapreneurial corporate renewal", Journal of Business Venturing, Vol. 8, pp. 383-9.

Mira, F.S. (2002), "On capital structure in the small and medium enterprises: the Spanish case”, working paper series, Instituto de Estudios Europeos - Universidad San Pablo CEU, Madrid.

Njoya, W. (1999), “An analysis of the interests and rights of corporate shareholders using property rights theory in law and economics", dissertation submitted for the Certificate of Postgraduate Study in Legal Studies, Faculty of Law, University of Cambridge, Cambridge. Pettigrew, A. and McNulty, T. (1995), "Power and influence in and around the boardroom", Human Relations, Vol. 48 No. 8, pp. 845-73.

Pinchot, G. III (1985), Intrepreneuring, Harper \& Row, New York, NY.

Pugliese, A. (2006). Determinants of Board Strategic Involvement in Small Firms: an Empirical Analysis of Norwegian Companies Best paper proceedings from the EURAM Boards and governance track in Oslo 2006, 37-54.

Schollhammer, H. (1982), "Internal corporate entrepreneurship", in Kent, C., Sexton, D. and Vesper, K. (Eds), Encyclopaedia of Entrepreneurship, Prentice-Hall, Englewood Cliffs, NJ. Shleifer, A. and Vishny, R. (1997), "A survey of corporate governance", Journal of Finance, Vol. 52 No. 2, pp. 737-83.

Steel, W.F. and Webster, L.M. (1991), "Small enterprises in Ghana: responses to adjustment", Industry Series paper No. 33, The World Bank Industry and Energy Department, Washington, DC.

Steel, W.F. and Webster, L.M. (1992), "How small enterprises have responded to adjustment", The World Bank Economic Review, Vol. 6 No. 3, pp. 423-38.

Storey, D.J. (1985), Small Firms in Regional Economics Development, Cambridge University Press, Cambridge.

Teal, F. (2002), "Background information on use of dataset: regional project on enterprise development (RPED) Ghana manufacturing sector survey waves I-V (1991-97)”, Centre for the Study of African Economies, Institute of Economics \& Statistics, University of Oxford, Oxford.

Thomi, W.H. and Yankson, P.W.K. (1985), "Small-scale industries and decentralization in Ghana: a preliminary report on small-scale industries in small and medium-sized towns in Ghana", Institut für Wirtschafts- und Socialgeographie, J.W. Goethe Universität Frankfurt/Accra.

Van den Heuvel J., Van Gils A. and Voordeckers W. (2006). Board Roles in Small and Medium-Sized Family Businesses: Performance and Importance. Corporate Governance- An International Review. Vol 14, No 5, 467-485. 
Van der Wijst, D. (1989), Financial Structure in Small Business: Theory, Tests and Applications, Lecture Notes in Economics and Mathematical Systems series, No. 320, Springer-Verlag, Berlin.

Varottil, U. (2010). Evolution and Effectiveness of Independent Directors in Indian Corporate Governance. Hastings Business Law Journal, 6(2), 281.

Weston, J.F. and Copeland, T.E. (1998), Managerial Finance, CBS College Publishing, New York, NY.

Wright, M. (Eds), Corporate Governance: Economic and Financial Issues, Oxford University Press, Oxford, pp. 1-17. 